\title{
Yield performance of apple rootstocks of the Geneva series on replanting soil
}

\author{
Frederico Denardi ${ }^{(1)}$, Marcus Vinícius Kvitschal(1) and Maraisa Crestani Hawerroth ${ }^{(1)}$
}

\begin{abstract}
(1)Empresa de Pesquisa Agropecuária e Extensão Rural de Santa Catarina, Estação Experimental de Caçador, Rua Abílio Franco, no 1.500, Bom Sucesso, Caixa Postal 591, CEP 89501-032 Caçador, SC, Brazil. E-mail: denardi.frederico@gmail.com, marcusvinicius@epagri.sc.gov.br, maraisahawerroth@epagri.sc.gov.br
\end{abstract}

\begin{abstract}
The objective of this work was to identify rootstocks with competitive agronomic potential to substitute those currently used in Southern Brazil for the Galaxy and Fuji Suprema apple scion cultivars cultivated on replanting soils. The experiment was carried out in the municipality of Lebon Regis, in the state of Santa Catarina, Brazil, from the 2009/2010 to the 2014/2015 crop season, in a randomized complete block design, with four replicates. The yield performance of the 'Galaxy' and 'Fuji Suprema' scions grafted on the G.056, G.202, G.213, G.814, G.896, G.969, M.9, and Marubakaido/M.9 rootstocks was evaluated. G.896 and G.814 stood out due to their superior annual and cumulative fruit yields, as well as to their greater yield regularity, although they showed lower ability of dwarfing the scion. The greatest average fruit weight of 'Galaxy' was obtained on G.056 and G.213. For 'Fuji Suprema', G.969 promoted smaller fruits, whereas the other rootstocks did not differ. All the evaluated rootstocks produced less suckers than Marubakaido/M.9 and less burrknots than M.9 and Marubakaido/M.9. In general, on replanting soil conditions, G.202 is promising among dwarfing rootstocks, mainly for 'Fuji Suprema'. G.056, G.814, and G.896 also stand out, and the two first are more specific for 'Fuji Suprema'.
\end{abstract}

Index terms: Malus, burrknots, fruit production, Fuji Suprema cultivar, Galaxy cultivar, suckers.

\section{Desempenho produtivo de porta-enxertos de macieira da série Geneva em solo de replantio}

Resumo - O objetivo deste trabalho foi identificar porta-enxertos com potencial agronômico competitivo para substituir os tradicionalmente usados no Sul do Brasil para as cultivares-copa de macieira Galaxy e Fuji Suprema cultivadas em solo de replantio. O experimento foi conduzido em Lebon Regis, no Estado de Santa Catarina, nas safras de 2009/2010 a 2014/2015, em delineamento experimental de blocos ao acaso, com quatro repetições. Avaliou-se o desempenho agronômico das copas 'Galaxy' e 'Fuji Suprema', enxertadas sobre G.056, G.202, G.213, G.814, G.896, G.969, M.9 e Marubakaido/M.9. G.896 e G.814 se destacaram pelas produções de frutos anual e acumulada superiores, bem como pela maior regularidade produtiva, embora tenham apresentado menor capacidade ananizante sobre a copa. As maiores massas médias de frutos de 'Galaxy' foram obtidas sobre G.056 e G.213. Para 'Fuji Suprema', G.969 proporcionou frutos menores, enquanto os demais porta-enxertos não diferiram entre si. Todos os porta-enxertos avaliados rebrotaram menos que Marubakaido/M.9 e produziram menos "burrknots" que M.9 e Marubakaido/M.9. No geral, nas condições de solo de replantio, G.202 mostra ser promissor entre os porta-enxertos ananizantes, principalmente para 'Fuji Suprema'. Destacam-se também G.056, G.814 e G.896, sendo os dois primeiros mais específicos para 'Fuji Suprema'.

Termos para indexação: Malus, burrknots, produção de frutos, cultivar Fuji Suprema, cultivar Galaxy, rebrotamento.

\section{Introduction}

Currently, the longevity of an apple (Malus spp.) orchard seldom exceeds 25 years due to the frequent replacement of scion cultivars and to the new technologies regarding planting density, which require that the most vigorous rootstocks be replaced by the most dwarfing ones (Petri et al., 2011). In addition, because of the low availability of virgin soils, there is a need to establish new orchards on replanting soils. However, as a rule, apple tree development and, consequently, yield performance may be seriously compromised when new orchards are planted on soils previously cultivated with temperate-zone fruit trees (Leinfelder \& Merwin, 2006). This is closely related 
to the phenomenon known as "apple replant disease" (ARD), characterized by noxious abiotic (toxins exuded by the previously cultivated plants and ethylene from root decomposition) and biotic (soil fungus, nematodes, bacteria, and actinomycetes) complexes (Zhu et al., 2014).

On replanting soil conditions, the performance of apple plants may also vary according to the used rootstock. In general, the most vigorous rootstocks are less affected by ARD than the dwarfing ones (Isutsa $\&$ Merwin, 2000), and the tolerance of their root system to harmful agents seems to play a crucial role (Leinfelder \& Merwin, 2006). In Southern Brazil, the most common pests affecting apple trees are collar root rot (Phytophthora cactorum) and woolly apple aphid (Eriosoma lanigerum); fortunately, several apple rootstocks of the Geneva series have simultaneous resistance to both of these pathogenic organisms (Denardi et al., 2015b).

In the Southern region of Brazil, the first apple orchards planted on replanting soils were grafted on the MM.111, MI.793, and M.25 British rootstocks; however, all of these induced excessive vigor to the scion and resulted in low bearing precocity, low yield performance, and insufficient fruit quality for the market (Robinson, 2011). During the 1990s, another rootstock, M.7, was used with relative success on replanting soils, but showed a strong emission of suckers on the tree collar and high susceptibility to woolly apple aphid (Denardi et al., 2015b). More recently, M.7 was replaced by the combination between the Marubakaido rootstock and the M.9 interstem (commonly called "filter"), which is the most commonly adopted in apple orchards in Southern Brazil (Denardi et al., 2013, 2015b). Even though this combination has shown good performance on replanting soils, it has certain limitations, including strong suckering on Marubakaido (Kvitschal \& Denardi, 2009), development of tumors on tree collars, and high sensitivity to some viruses (Soejima et al., 1998). It also requires double grafting and a subsequent cultivation of young trees in the nursery for two years, increasing production costs. Presently, M.9, one of the most planted rootstocks on virgin soils in Southern Brazil, has shown to be highly efficient in inducing early bearing, high yield, and good fruit quality; however, it has unsatisfactory tolerance to ARD (Robinson, 2011).
Since most of the Geneva apple rootstocks are resistant to collar root rot and to woolly apple aphid (Robinson, 2011; Fazio et al., 2013) and some have adequate tolerance to ARD (Auvil et al., 2011; Fazio et al., 2012), researches have been conducted in Southern Brazil aiming to evaluate their performance in different growing conditions (Denardi et al., 2015a, 2016; Pasa et al. 2016, 2017). In the USA, Leinfelder \& Merwin (2006) observed that the G.210 and G.30 rootstocks of the Geneva series induced greater vigor and yield to the scion than M.7.

The objective of this work was to identify rootstocks with competitive agronomic potential to substitute those currently used in Southern Brazil for the Galaxy and Fuji Suprema apple scion cultivars cultivated on replanting soils.

\section{Materials and Methods}

The experiment was established in 2007 in an orchard belonging to the company Fischer Fraiburgo Agrícola Ltda., located in the municipality of Lebon Regis, in the Midwest of the state of Santa Catarina, Brazil (26 $90^{\prime} 95^{\prime \prime} \mathrm{S}, 50^{\circ} 83^{\prime} 27^{\prime \prime} \mathrm{W}$, at $1,050 \mathrm{~m}$ altitude). The evaluations were carried out during six crop seasons, from $2009 / 2010$ to $2014 / 2015$. Accumulated winter chill and annual rainfall were recorded for the 2008-2014 period (Table 1). The area was previously cultivated with the 'Gala' and 'Fuji' apples (Malus $x$ domestica, Borkh.), both grafted on the MM.106 rootstock, for 21 years up to 1 year before the beginning of the experiment. This apple orchard was eliminated during the 2006 winter by cutting the scion with a chain saw and removing the roots with a plow and tractor. The remaining vegetative material was burned outside the experimental area, which was kept as fallow land for another year, representing the replanting soil condition.

Soil analysis before the start of the experiment revealed the following composition at the $0-20$ and 20-40-cm depths, respectively: 6.0 and $3.0 \mathrm{mg} \mathrm{kg}^{-1} \mathrm{P}$; 0.35 and 0.16 meq $100 \mathrm{~L}^{-1} \mathrm{~K} ; 15$ and $11 \mathrm{meq} 100 \mathrm{~L}^{-1} \mathrm{Ca}$; 7.8 and 6.4 meq $100 \mathrm{~L}^{-1} \mathrm{Mg} ; 5.2 \%$ organic matter; and $0.10 \%$ Al. Prior to the beginning of the experiment, the soil was subsoiled, at the $40-50-\mathrm{cm}$ depth, with subsequent plowing and leveling with a disc harrow; fertilization was performed according to the technical recommendations for apple cultivation in Brazil (Epagri, 2006).

Pesq. agropec. bras., Brasília, v.53, n.8, p.924-933, Aug. 2018 DOI: $10.1590 / \mathrm{S} 0100-204 X 2018000800007$ 
The experimental design was a randomized complete block, with four replicates of three plants per plot. The studied scion cultivars were Galaxy and Fuji Suprema (M. domestica), grafted on the following eight rootstocks: G.056, G.202, G.213, G.814, G.896, and G.969, as well as M.9 and the combination between the Marubakaido rootstock and the M.9 interstem (Marubakaido/M.9), which were used as controls; for more details on the main characteristics of most of these rootstocks see Denardi et al. (2015b). The trees were spaced at $5.0 \mathrm{~m}$ between rows and $2.0 \mathrm{~m}$ between plants; to ensure cross-pollination, Galaxy and Fuji Suprema were planted on alternate rows, a tree arrangement traditionally used by apple growers in Southern Brazil for commercial orchards. The thinning of excess fruits was performed manually during each crop season when the fruits reached $\approx 1.0$ $\mathrm{cm}$ diameter, maintaining two fruits per inflorescence on apical buds and one fruit per inflorescence on lateral buds, with a spacing of at least $10 \mathrm{~cm}$ between flower clusters.

The traits average fruit weight, cumulative yield, number of suckers on the rootstock, number of burrknots (nodules of aerial root primordia) on the rootstock, trunk cross-sectional area (TCSA), and yield efficiency were assessed based on the treatment factors scion cultivar, rootstock, and their interactions, on a $2 \times 8$ factorial arrangement. Annual fruit yield, however, was evaluated using the treatment factors scion cultivar, rootstock, crop season, and their interactions, on a $2 \times 8 \times 6$ factorial arrangement.

Table 1. Weather data ${ }^{(1)}$ for the period from 2008 to 2014 when Galaxy and Fuji Suprema apple (Malus domestica) scion cultivars were grafted on Geneva series rootstocks and cultivated on replanting soil in the municipality of Lebon Regis, in the state of Santa Catarina, Brazil.

\begin{tabular}{cccc}
\hline Year & $\begin{array}{c}\text { Chilling } \\
\text { hours } \leq 7,2^{\circ} \mathrm{C}\end{array}$ & $\begin{array}{c}\text { Chilling } \\
\text { units }^{(2)}\end{array}$ & $\begin{array}{c}\text { Cumulative annual } \\
\text { rainfall }(\mathrm{mm})\end{array}$ \\
\hline 2008 & 568 & 1,437 & 1,424 \\
2009 & 607 & 1,467 & 1,723 \\
2010 & 557 & 1,415 & 1,369 \\
2011 & 720 & 1,416 & 1,583 \\
2012 & 434 & 1,153 & 1,601 \\
2013 & 593 & 1,384 & 1,798 \\
2014 & 362 & 678 & 1,588 \\
\hline
\end{tabular}

${ }^{(1)}$ Collected at the weather station of Fraiburgo Agrícola Ltda., in Lebon Regis, in the state of Santa Catarina, Brazil. (2) Obtained according to the North Carolina model (Ebert et al., 1986).
Specifically, annual fruit yield (kilograms per plant) was determined by measuring the total weight of the fruit harvested from each plant, during each crop season from 2009/2010 to 2014/2015. Cumulative yield (kilograms per plant) was calculated as the sum of annual fruit yield from $2009 / 2010$ to $2014 / 2015$. TCSA (square centimeters) was estimated by: TCSA $=\pi \mathrm{d}^{2} / 4$, where $d$ is the diameter of the scion trunk, measured with a caliper at $5.0 \mathrm{~cm}$ above the graft union in the 2013/2014 crop season, when the trees reached six years of age. Yield efficiency (kilograms of fruits per square centimeter of TCSA) was determined according to Czynczyk \& Bielicki (2012), considering the ratio between the fruit yield per plant in the 2013/2014 crop season and the TCSA measured during the same season. The average fruit weight (grams) was calculated as the ratio between the weight of total fruit production and the number of fruits harvested per plant, considering the average performance of the six evaluated crop seasons. The presence of suckers emerging from the rootstocks on the plant collar and the emission of burrknots on the trunk of the rootstocks during the 2014/2015 crop season was also assessed; both traits were expressed as units per plant.

To meet the assumptions of the analysis of variance, for number of suckers and of burrknots, data were transformed using $\left[(\mathrm{x}+1)^{0.5}\right]$. The analysis of variance was applied to identify the effects of the treatment factors and their respective interactions. For the traits that revealed statistical significance by the F-test, at $5 \%$ probability, the averages were compared by the Scott-Knott test, also at 5\% probability. All statistical analyses were performed using the Sisvar software (Ferreira, 2011).

\section{Results and Discussion}

Both scion cultivars and rootstocks affected the performance of cumulative yield, TCSA, and yield efficiency, when evaluated individually, and of average fruit weight, when combined. Denardi et al. (2016) reported significant effects of rootstocks on TCSA, cumulative fruit yield, yield efficiency, and average fruit weight for 'Gala' grafted on Geneva apple rootstocks, as well as of the interaction between rootstock and crop season on annual fruit yield.

From the 2009/2010 to the 2014/2015 crop season, annual fruit yield varied according to the combination 
between scion cultivar and rootstock (scion cultivar $\times$ rootstock interaction) and to the behavior of the scion cultivar and rootstock throughout the evaluated crop seasons (scion cultivar $\times$ crop season and rootstock $x$ crop season interaction). This trait was also significantly affected by scion cultivar, rootstock, and crop season individually. Fioravanço et al. (2016) found varying yield efficiency for nine apple cultivars in the municipality of Vacaria, in the state of Rio Grande do Sul, Brazil, when grafted on M.9 and Marubakaido/M.9 during six crop seasons. In the USA, Autio et al. (2011) also observed significant variation on the cumulative fruit yield and yield efficiency of the 'Fuji' and 'McIntosh' scions grafted on several different rootstocks, including M.9 and G.202.

The average performance of the scion cultivars varied from 8.63 to $28.13 \mathrm{~kg}$ per plant for 'Galaxy' and from 6.44 to $46.46 \mathrm{~kg}$ per plant for 'Fuji Suprema', between the 2009/2010 and 2014/2015 crop seasons, respectively (Table 2). According to the technical team of Fischer Fraiburgo Agrícola Ltda., biennial bearing was observed on 'Fuji Suprema' in 2011/2012 and on 'Galaxy' in 2012/2013 seasons at the surroundings orchards of this study. Biennial bearing is a common fact in apple orchards and has also been reported in the literature for 'Gala' and 'Fuji' clones (Denardi et al., 2015a, 2016; Fioravanço et al., 2016). In this study the average annual fruit yield was significantly lower during 2011/2012 and 2012/2013, compared with the 2010/2011 crop season, which is partially explained by the adoption in the experiment the same management applied in the surrounding orchards. The cultivars evaluated in the present study are sensitive to specific climatic conditions during crucial stages for the apple orchard, such as blooming, which typically vary among years and sites in Southern Brazil. This region is characterized by a subtropical climate, which is usually associated with important physiological aspects related to apple tree fruiting, quality of flowering buds, carbohydrate solubilization of the plant, activity of vegetative development, and time and intensity of fruit thinning, for example.

Compared with 'Fuji Suprema', 'Galaxy' had a lower annual fruit yield in three of the six crops seasons evaluated, i.e., in 2011/2012, 2013/2014, and 2014/2015. This result can be attributed to the different size of the canopy of the studied cultivars, since 'Galaxy' is less vigorous than 'Fuji Suprema'. On virgin soil conditions,
Denardi et al. (2015a) also found that 'Galaxy' had a lower yield performance than 'Fuji' when both were grafted on Geneva rootstocks, including G.202. Regarding rootstock effect during crop seasons, in 2009/2010, all eight rootstocks studied induced similar average yield in both scion cultivars (Table 2). This performance was expected because the plants were at the beginning of the reproductive phase, when fruit yield is usually relatively low. However, in the five following crop seasons, the average annual fruit yield differed among rootstocks, and G.814, G.896, G.056, and G.202 stood out due to their superior overall performance during the period. In a study in the USA, Fazio et al. (2013) found that the elite rootstocks of the Geneva series were superior to standard commercial apple rootstocks, such as M.9, M.26, M.7, and MM.106, regarding cumulative yield and yield efficiency.

The G.814 rootstock showed the best fruit yield regularity during the six crop seasons evaluated, with higher average annual fruit yield, ranging from 11.39 to $53.29 \mathrm{~kg}$ per plant in the $2009 / 2010$ and $2014 / 2015$ crop seasons, respectively (Table 2). Pasa et al. (2016), in a study in the municipality of São Joaquim, in the state of Santa Catarina, Brazil, verified that G.814 and G.056 cultivated on virgin soil, despite being less vigorous than Marubakaido/M.9, showed similar yield performance when grafted with the Imperial Gala and Fuji Mishima scion cultivars. Robinson et al. (2011) observed that, in the USA, G.814 presented higher yield efficiency than M.7; however, both have similar ability to control the vigor of the scion (Russo et al., 2007). G.896 had lower annual fruit yield than G.814 in the last two crop seasons - 2013/2014 and 2014/2015 -, and also stood out regarding fruit yield regularity, showing higher average fruit yield than M.9 and Marubakaido/M.9 during four of the six seasons. The average annual fruit yield of the G.056 and G.202 rootstocks was also higher or similar to that of M.9 and Marubakaido/M.9 during all crop seasons. According to White \& Tustin (2000), the high performance of G.202 was associated with its better tolerance to ARD on replanting soil in New Zealand.

In general, the rootstocks that induced the lowest average annual fruit yield in both scions were G.213 and G.969 (Table 2), which suggests that they may not be effective on replanting soils in Southern Brazil. It should be pointed out, however, that, on virgin soil conditions, Denardi et al. (2015a) observed that these 
rootstocks induced higher cumulative yield to 'Gala' and 'Fuji', compared with M.9. Moreover, Robinson (2011) reported that the G.969 rootstock showed tolerance to ARD during evaluations carried out in the USA; however, according to Johnson (2000), ARD is site-specific because the biotic/abiotic complexes that characterize it differ from one region to another, as well as the resistance or tolerance among rootstocks in each apple cultivation system.

Considering the scion vs. rootstock interaction for annual fruit yield, a superior performance was observed for 'Fuji Suprema' when grafted on most of the rootstocks, except on G.896, M.9, and Marubakaido/M.9, which showed similar results for both scion cultivars (Table 3). When evaluating other scion cultivars, Denardi et al. (2016) found higher yield for 'Fuji' on three of the studied rootstocks (G.202, G.30, and G.210), and for 'Gala' only on the more vigorous MM.111.

For the Galaxy scion cultivar, the highest average annual fruit yield was obtained on the G.814 and G.896 rootstocks. G.056 and G.202 also stood out for inducing a yield performance equivalent to that of the M.9 and Marubakaido/M.9 controls (Table 3). According to Fazio et al. (2013), several Geneva rootstocks have a rich root system with thin roots, i.e., high absorbers/ structural roots ratio, which may induce better yield performance and higher ARD tolerance. G.210, for example, has been shown to be tolerant to ARD (Auvil et al., 2011), which may be attributed to the twice deeper distribution of its roots in the soil, compared with M.7.

For 'Fuji Suprema', with the exception of G.969, all Geneva rootstocks, especially G.814, G.896, and G.056, induced yield performance equivalent or better than that of the traditional M.9 and Marubakaido/M.9. When comparing the results for both scion cultivars, G.056, G.202, G.213, and G.814 were notably more specific for 'Fuji Suprema', inducing higher annual fruit yield. This suggests that, despite showing one of the worst performances for 'Galaxy', G.213 can still be a good rootstock for 'Fuji Suprema', since it induced similar annual fruit yields to those obtained on M.9 and Marubakaido/M.9. Regarding this trait, G.896 did not show specificity to either Fuji Suprema or Galaxy, similarly to M.9 and the combination Marubakaido/M.9, suggesting its efficient use for both scion cultivars. The lowest average annual fruit yield for the six crop seasons was obtained when 'Galaxy' was grafted on G.213 and G.969, and the lowest when 'Fuji Suprema' was grafted on G.969. Denardi et al. (2015a) evaluated eight rootstocks, six belonging to the Geneva series, and observed superior yield performance of 'Gala' grafted on G.969 and G.213.

Table 2. Performance of apple (Malus domestica) scion cultivars on different rootstocks regarding annual fruit yield from the $2009 / 2010$ to the $2014 / 2015$ crop season, when cultivated on replanting soil, in the municipality of Lebon Regis, in the state of Santa Catarina, Brazil ${ }^{(1)}$.

\begin{tabular}{|c|c|c|c|c|c|c|}
\hline \multirow[t]{2}{*}{ Genotype } & \multicolumn{6}{|c|}{ Annual fruit yield (kg per plant) } \\
\hline & $2009 / 2010$ & $2010 / 2011$ & $2011 / 2012$ & $2012 / 2013$ & $2013 / 2014$ & $2014 / 2015$ \\
\hline & \multicolumn{6}{|c|}{ Rootstocks } \\
\hline G.056 & $5.12 \mathrm{aD}$ & $27.05 \mathrm{aB}$ & $13.84 \mathrm{bC}$ & $12.58 \mathrm{aC}$ & $26.98 \mathrm{bB}$ & $44.40 \mathrm{bA}$ \\
\hline G.202 & $6.76 \mathrm{aC}$ & $23.32 \mathrm{aB}$ & $13.72 b \mathrm{~b}$ & $12.09 \mathrm{aC}$ & $21.42 \mathrm{cB}$ & $37.38 \mathrm{bA}$ \\
\hline G.213 & $6.84 \mathrm{aB}$ & $19.46 \mathrm{bA}$ & $8.60 \mathrm{bB}$ & $5.65 \mathrm{bB}$ & $15.53 \mathrm{dA}$ & $21.69 \mathrm{cA}$ \\
\hline G.814 & $11.39 \mathrm{aE}$ & $31.66 \mathrm{aC}$ & $24.38 \mathrm{aD}$ & $16.96 \mathrm{aE}$ & $40.58 \mathrm{aB}$ & $53.29 \mathrm{aA}$ \\
\hline G.896 & $10.19 \mathrm{aD}$ & $29.52 \mathrm{aB}$ & $23.57 \mathrm{aC}$ & $17.14 \mathrm{aC}$ & $31.79 \mathrm{bB}$ & $44.10 \mathrm{bA}$ \\
\hline G.969 & $5.97 \mathrm{aB}$ & $11.35 \mathrm{cB}$ & $7.15 \mathrm{bB}$ & $5.14 \mathrm{bB}$ & $9.41 \mathrm{~dB}$ & $18.91 \mathrm{cA}$ \\
\hline M.9 & $5.86 \mathrm{aC}$ & $17.31 \mathrm{bB}$ & $11.32 \mathrm{bC}$ & $9.82 \mathrm{bC}$ & $21.72 \mathrm{cB}$ & $39.40 \mathrm{bA}$ \\
\hline \multirow[t]{2}{*}{ Marubakaido/M.9 ${ }^{(2)}$} & $8.16 \mathrm{aC}$ & $20.17 \mathrm{bB}$ & $12.50 \mathrm{bC}$ & $7.49 \mathrm{bC}$ & $20.68 \mathrm{cB}$ & $39.18 \mathrm{bA}$ \\
\hline & \multicolumn{6}{|c|}{ Scion cultivar } \\
\hline Galaxy & $8.63 \mathrm{aC}$ & $21.60 \mathrm{aB}$ & $11.12 \mathrm{bC}$ & $11.70 \mathrm{aC}$ & $18.63 \mathrm{bB}$ & $28.13 \mathrm{bA}$ \\
\hline Fuji Suprema & $6.44 \mathrm{aF}$ & $23.35 \mathrm{aC}$ & $17.65 \mathrm{aD}$ & $10.02 \mathrm{aE}$ & $28.40 \mathrm{aB}$ & $46.46 \mathrm{aA}$ \\
\hline Average (season) & $7.54 \mathrm{D}$ & $2.48 \mathrm{~B}$ & $14.38 \mathrm{C}$ & $10.86 \mathrm{D}$ & $23.52 \mathrm{~B}$ & $37.30 \mathrm{~A}$ \\
\hline Coefficient of variation (\%) & 85.69 & 28.74 & 44.93 & 59.49 & 27.47 & 17.32 \\
\hline
\end{tabular}

${ }^{(1)}$ Means followed by equal letters, lowercase in the columns and uppercase in the lines, do not differ by the Scott-Knott test, at $5 \%$ probability. ${ }^{(2)}$ Combination of the Marubakaido rootstock with the M.9 interstem. 
Cumulative fruit yield, though not affected by the scion cultivar $\times$ rootstock interaction, showed a similar tendency to that of annual fruit yield regarding the overall performance of rootstocks and scions (Tables 3 and 4). A greater yield of $85.87 \mathrm{~kg}$ per plant was observed for 'Fuji Suprema', compared with that of $71.67 \mathrm{~kg}$ per plant for 'Galaxy'. The G.814 and G.896 rootstocks induced higher cumulative fruit yield of 124.97 and $112.20 \mathrm{~kg}$ per plant, respectively, on average for both scion cultivars. It should be noted that, despite inducing lower cumulative fruit yields than G.814 and G.896, the performance of the G.056 and G.202 rootstocks was equivalent to that of M.9 and Marubakaido/M.9 for this trait.

In general, 'Fuji Suprema' produced fruits with an average weight of $133.14 \mathrm{~g}$, which were larger than those of 'Galaxy', with $125.41 \mathrm{~g}$ (Table 3). For 'Fuji Suprema', only the G.213 and G.056 rootstocks did not induce greater-sized fruit. However, for 'Galaxy', the largest fruits, weighing 134.86 and $133.92 \mathrm{~g}$, respectively, were obtained on both of these rootstocks, even when compared with the dwarfing M.9 rootstock, considered as one of the most efficient for inducing large-sized fruits to the scion (Webster, 2002). Denardi et al. (2015a) also found that, for 'Gala', the greatest fruit weight was obtained on G.213, whereas the lowest was induced by G.896 and G.969. When grafted on G.814, 'Galaxy' produced fruits with an average weight of $127.47 \mathrm{~g}$, larger than that on Marubakaido/M.9, with $123.22 \mathrm{~g}$, but equivalent to that on M.9, with 127.00 g. On G.202 and G.896, 'Galaxy' produced fruits weighing 122.44 and $123.10 \mathrm{~g}$, respectively, which are values similar to those obtained on the combination Marubakaido/M.9, but lower than those on M.9. The lowest average fruit weight of 'Galaxy' (111.33 g) and 'Fuji Suprema' (124.65 g) was obtained on the G.969 rootstock, which corroborates the results of Denardi et al. (2015a) in a study in the municipality of Fraiburgo, in the state of Santa Catarina, Brazil. For 'Fuji Suprema', all rootstocks, except G.969, did not differ and induced the production of fruits with an average weight equivalent to that obtained on M.9 and Marubakaido/M.9.

Regarding TCSA, which indicates the capacity of the rootstock to control scion vigor (Marcon Filho et al., 2009), G.814 and G.896 induced the highest averages of 52.30 and $58.92 \mathrm{~cm}^{2}$, respectively, compared with Marubakaido/M.9, with $47.07 \mathrm{~cm}^{2}$, a value that indicates medium to high vigor (Table 4). The G.213 and G.969 rootstocks showed TCSA averages of 27.24 and $25.71 \mathrm{~cm}^{2}$, respectively, which were lower than those of $37.99 \mathrm{~cm}^{2}$ for the dwarfing M.9 and of $38.75 \mathrm{~cm}^{2}$ for G.202, both with equivalent vigor. The latter rootstock also revealed a capacity to control the vigor of the scions similar to that of M.9; however, in a study carried out on virgin soil, in the state of Santa Catarina, Brazil, from the 1996/1997 to the 2003/2004 crop season, Denardi et al. (2015a) found that G.202 had a slightly greater TCSA. In other studies on virgin soil, G.213 (Denardi et al., 2015a) and G.969 (Russo et al., 2007; Robinson et al., 2011) showed TCSA similar to that of M.9; this may be an indicative

Table 3. Performance of apple (Malus domestica) rootstocks grafted with Galaxy and Fuji Suprema scion cultivars (SC) regarding annual fruit yield and average fruit weight from the 2009/2010 to the 2014/2015 crop season, when cultivated on replanting soil in the municipality of Lebon Regis, in the state of Santa Catarina, Brazil ${ }^{(1)}$.

\begin{tabular}{|c|c|c|c|c|c|c|}
\hline \multirow{2}{*}{$\begin{array}{l}\text { Rootstock } \\
\text { (R) }\end{array}$} & \multicolumn{3}{|c|}{ Annual fruit yield (kg per plant) } & \multicolumn{3}{|c|}{ Average fruit weight (g) } \\
\hline & Galaxy & Fuji Suprema & Average (R) & Galaxy & Fuji Suprema & Average (SC) \\
\hline G.056 & $18.69 \mathrm{bB}$ & $24.64 \mathrm{bA}$ & $21.66 \mathrm{~b}$ & $133.92 \mathrm{aA}$ & $133.32 \mathrm{aA}$ & $133.62 \mathrm{a}$ \\
\hline G.202 & $17.11 \mathrm{bB}$ & $21.2 \mathrm{cA}$ & $19.1 \mathrm{c}$ & $122.44 \mathrm{cB}$ & $132.39 \mathrm{aA}$ & $127.42 \mathrm{a}$ \\
\hline G.213 & $7.14 \mathrm{cB}$ & $18.78 \mathrm{cA}$ & $12.6 \mathrm{~d}$ & $134.86 \mathrm{aA}$ & $133.56 \mathrm{aA}$ & $134.21 \mathrm{a}$ \\
\hline G.814 & $25.40 \mathrm{aB}$ & $34.02 \mathrm{aA}$ & $29.71 \mathrm{a}$ & $127.47 \mathrm{bB}$ & $137.41 \mathrm{aA}$ & $132.44 a$ \\
\hline G.896 & $25.64 \mathrm{aA}$ & $26.47 \mathrm{bA}$ & $26.05 \mathrm{a}$ & $123.10 \mathrm{cB}$ & $134.25 \mathrm{aA}$ & $128.67 \mathrm{a}$ \\
\hline G.969 & $6.48 \mathrm{cB}$ & $12.83 \mathrm{dA}$ & $9.66 \mathrm{~d}$ & $111.33 \mathrm{~dB}$ & $124.65 \mathrm{bA}$ & $117.99 \mathrm{~b}$ \\
\hline M.9 & $15.94 \mathrm{bA}$ & $19.20 \mathrm{cA}$ & $17.57 \mathrm{c}$ & $127.00 \mathrm{bB}$ & $134.80 \mathrm{aA}$ & $130.88 \mathrm{a}$ \\
\hline Marubakaido/M.9 $9^{(2)}$ & $16.68 \mathrm{bA}$ & $19.38 \mathrm{cA}$ & $18.03 \mathrm{c}$ & $123.22 \mathrm{cB}$ & $134.77 \mathrm{aA}$ & $128.99 \mathrm{a}$ \\
\hline Average (SC) & $16.63 \mathrm{~B}$ & $22.06 \mathrm{~A}$ & - & $125.41 \mathrm{~B}$ & $133.14 \mathrm{~A}$ & - \\
\hline
\end{tabular}

${ }^{(1)}$ Means followed by equal letters, lowercase in the columns and uppercase in the lines, do not differ by the Scott-Knott test, at $5 \%$ probability.

${ }^{(2)}$ Combination of the Marubakaido rootstock with the M.9 interstem. 
that, in the present study, the poor development of 'Galaxy' trees grafted on these rootstocks was due to their intolerance to ARD. White \& Tustin (2000), in New Zealand, observed that, on replanting soil, G.202 had a TCSA similar to that of M.26, a more vigorous rootstock than M.9. Among the studied rootstocks, G.814 and G.896 were the least efficient in controlling the vigor of the scion, whereas G.213 and G.969 were the most efficient.

Due to its lower TCSA, the G.202 rootstock showed an average yield efficiency of $2.14 \mathrm{~kg} \mathrm{~cm}^{-2}$ (Table 4), which was higher than that of both controls. In fact, all Geneva rootstocks had higher yield efficiency than M.9 (1.74 $\left.\mathrm{kg} \mathrm{cm}^{-2}\right)$ and Marubakaido/M.9 $\left(1.51 \mathrm{~kg} \mathrm{~cm}^{-2}\right)$, except G.969, with $1.61 \mathrm{~kg} \mathrm{~cm}^{-2}$. Studies have shown a tendency towards a negative correlation between yield efficiency induced by the rootstock to the scion and canopy vigor, which is reflected in low TCSA averages (Marcon Filho et al., 2009; Robinson et al., 2011); however, G.969 did not follow this pattern, as it did not induce high yield efficiency in the scion cultivars, despite being one of the most dwarfing rootstocks and having the lowest TCSA. This could be due to ARD intolerance, since, in another research, G.969 induced better yield efficiency in 'Gala' than M.9, even with higher TCSA averages (Denardi et al., 2015a).
The average yield efficiency of the Galaxy scion cultivar $\left(2.09 \mathrm{~kg} \mathrm{~cm}^{-2}\right)$ was greater than that of Fuji Suprema (1.77 $\mathrm{kg} \mathrm{cm}^{-2}$ ) (Table 4). Since 'Galaxy' is less vigorous, this behavior could be associated with the tendency of a negative correlation between vigor and yield efficiency in apple orchards (Denardi et al., 2015b). This was evident in the present study, where the lower TCSA $\left(34.28 \mathrm{~cm}^{2}\right)$ of 'Galaxy', compared with that of 'Fuji Suprema' $\left(48.65 \mathrm{~cm}^{2}\right)$, resulted in a better yield efficiency. According to Czynczyk \& Bielicki (2012), yield efficiency is one of the traits that best represents the yield potential of a scion. This suggests that, even though 'Fuji Suprema' had greater fruit production (annual and cumulative fruit yield), 'Galaxy' has a greater yield potential due to its greater yield efficiency. The higher canopy volume of 'Fuji Suprema', although resulting in a greater yield per plant, requires a wider layout for cultivation, culminating in a lower number of plants per unit of area and possibly in a lower number of fruits per hectare.

All the studied Geneva rootstocks produced less suckers than the combination Marubakaido/M.9 (Table 4). The G.213, G.814, G.896, and G.969 rootstocks, for example, produced less than one sucker per plant on average, whereas Marubakaido/M.9 produced more than 23 suckers per plant. Kvitschal

Table 4. Incidence of burrknots and suckers, cumulative yield, trunk cross-sectional area (TCSA) in the sixth year, and yield efficiency for the Galaxy and Fuji Suprema apple (Malus domestica) scion cultivars grafted on different rootstocks and cultivated on replanting soil from the 2009/2010 to the 2014/2015 crop season, in the municipality of Lebon Regis, in the state of Santa Catarina, Brazil ${ }^{(1)}$.

\begin{tabular}{|c|c|c|c|c|c|}
\hline \multirow[t]{3}{*}{ Genotype } & \multicolumn{3}{|c|}{ Crop seasons from $2009 / 2010$ to $2014 / 2015$} & \multicolumn{2}{|c|}{ 2013/2014 crop season } \\
\hline & Suckers $^{(2)}$ & Burrknots $^{(2)}$ & \multirow{2}{*}{$\begin{array}{l}\text { Cumulative yield } \\
\text { (kg per plant) }\end{array}$} & \multirow{2}{*}{$\begin{array}{l}\text { TCSA } \\
\left(\mathrm{cm}^{2}\right)\end{array}$} & \multirow{2}{*}{$\begin{array}{l}\text { Yield efficiency } \\
\left(\mathrm{kg} \mathrm{cm}^{-2}\right)\end{array}$} \\
\hline & ------------( & ant)------------ & & & \\
\hline & \multicolumn{5}{|c|}{ Rootstock } \\
\hline G.056 & $3.41 \mathrm{~b}$ & $0.71 \mathrm{~b}$ & $85.56 \mathrm{~b}$ & $43.74 b$ & $1.99 \mathrm{a}$ \\
\hline G.202 & $1.09 \mathrm{c}$ & $0.38 \mathrm{~b}$ & $77.30 \mathrm{~b}$ & $38.75 \mathrm{c}$ & $2.14 \mathrm{a}$ \\
\hline G.213 & $0.46 \mathrm{c}$ & $0.19 \mathrm{~b}$ & $56.07 \mathrm{c}$ & $27.24 \mathrm{~d}$ & $2.13 \mathrm{a}$ \\
\hline G.814 & $0.83 \mathrm{c}$ & $0.44 \mathrm{~b}$ & $124.97 \mathrm{a}$ & $52.30 \mathrm{a}$ & $2.41 \mathrm{a}$ \\
\hline G.896 & $0.55 \mathrm{c}$ & $0.54 \mathrm{~b}$ & $112.20 \mathrm{a}$ & $58.92 \mathrm{a}$ & $1.93 \mathrm{a}$ \\
\hline G.969 & $0.42 \mathrm{c}$ & $0.17 \mathrm{~b}$ & $39.03 \mathrm{c}$ & $25.71 \mathrm{~d}$ & $1.61 \mathrm{~b}$ \\
\hline M.9 & $1.43 \mathrm{c}$ & $1.46 \mathrm{a}$ & $66.04 \mathrm{~b}$ & $37.99 \mathrm{c}$ & $1.74 \mathrm{~b}$ \\
\hline \multirow[t]{2}{*}{ Marubakaido/M.9 ${ }^{(3)}$} & $23.01 \mathrm{a}$ & $1.26 \mathrm{a}$ & $68.99 \mathrm{~b}$ & $47.07 \mathrm{~b}$ & $1.51 \mathrm{~b}$ \\
\hline & \multicolumn{5}{|c|}{ Scion cultivar } \\
\hline Galaxy & - & - & $71.67 \mathrm{~b}$ & $34.28 b$ & $2.09 \mathrm{a}$ \\
\hline Fuji Suprema & - & - & $85.87 \mathrm{a}$ & $48.65 \mathrm{a}$ & $1.77 \mathrm{~b}$ \\
\hline
\end{tabular}

${ }^{(1)}$ Means followed by equal letters, lowercase in the columns, do not differ by the Scott-Knott test, at $5 \%$ probability. ${ }^{(2)}$ Obtained using data of the annual evaluation, when the highest incidence for each trait was observed. Burrknots were counted on the M.9 interstem grafted on the Marubakaido rootstock. ${ }^{(3)}$ Combination of the Marubakaido rootstock with the M.9 interstem. 
\& Denardi (2009) also observed more suckers on Marubakaido/M.9, compared with four Japanese rootstocks of the JM series. Soejima et al. (1998) highlighted that, despite being used in around $80 \%$ of the apple orchards in Japan, due to its valuable characteristics for commercial orchards, the Marubakaido rootstock causes strong suckering on the plant collar and is highly sensitive to viruses. In studies with Geneva rootstocks carried out in the USA, Robinson et al. (2011) found that G.202, G.814, and G.969 produced less suckers than M.9, and Russo et al. (2007) that, among these same rootstocks, only G.202 produced more suckers than M.9.

The Geneva rootstocks were also less susceptible to burrknots, showing a low number of these structures along the tree trunk (Table 4). These results corroborate those of Kain \& Robinson (2005), who did not observe burrknots on several Geneva rootstocks in the USA. In the present study, 1.46 and 1.26 burrknots were present along the tree trunks of M.9 and of the combination Marubakaido/M.9, respectively, which are significantly higher averages than those of the Geneva rootstocks. Studies conducted in the Czech Republic suggested that burrknots on apple tree trunks can restrict the development of the plant, affecting fruit production, and may also facilitate the introduction of canker diseases, which could cause premature tree death (Küdela et al., 2009).

The obtained results show that the number of suckers and burrknots varied according to the rootstock, but were unaffected by other factors. This may be why there are no know reports in the literature about the effect of the scion on the formation of burrknots and suckers on rootstocks.

Consideringall the traits evaluated in the presentstudy, the G.814 and G.896 rootstocks stood out for inducing good vigor to the scion on replanting soil. Additionally, they induced greater annual and cumulative fruit yield, better yield efficiency, and a lower incidence of suckers on the tree collar and of burrknots on the trunk. G.814 was more specific for 'Fuji Suprema', whereas the performance of G.896 suggests equivalent efficiency for both scion cultivars; however, since the capacity of these rootstocks to control the vigor of the scion is lower than that of Marubakaido/M.9, other factors should also be considered in future studies, such as plant spacing, planting depth, and fertility of the soil where the orchard will be planted, as well as adequate training and pruning managements of young plants during their development.

Among the rootstocks with vigor similar to that of the combination Marubakaido/M.9, G.056 showed to be a good alternative for replanting soils. Specifically among the more dwarfing rootstocks, G.202 had a great competitive potential for these types of soils, since it induced high yield efficiency and had annual and cumulative yields similar to those of M.9. When grafted on G.202, 'Fuji Suprema' showed superior performance, with higher average annual fruit yield and weight. Denardi et al. (2015a) also found that, among the dwarfing rootstocks evaluated, G.202 showed better specificity for 'Fuji Suprema'. Likewise, White \& Tustin (2000) reported that G.202 was one of the most promising in studies carried out in New Zealand, both on virgin and on replanting soils. In the present study, the G.213 rootstock, which stood out in other works regarding these same traits (Denardi et al., 2015a, 2016), showed a lower performance than expected. It should be pointed out, however, that there are no known reports in the literature of this rootstock on replanting soils; therefore, complementary studies are necessary for a better characterization and possible identification of the real causes for the worst performance of G.213 in the assessed growing conditions.

\section{Conclusions}

1. The G.896 and G.814 rootstocks induce more vigor to the Galaxy and Fuji Suprema apple (Malus domestica) scion cultivars than M.9 and the combination Marubakaido/M.9 on replanting soils.

2. On replanting soils, the G.814 and G.896 rootstocks induce greater fruit yield and better yield efficiency to the Galaxy and Fuji Suprema scion cultivars than M.9 and Marubakaido/M.9.

3. The G.056, G.202, G.213, and G.814 rootstocks are more promising for 'Fuji Suprema' because they induce greater fruit yield than when grafted with 'Galaxy'.

4. The G.056 and G.213 rootstocks induce larger fruit size to 'Galaxy' than M.9 and the combination Marubakaido/M.9 on replanting soil.

5. The G.056, G.202, G.213, G.814, G.896, and G.969 rootstocks are less susceptible to suckering on the plant collar and to the emission of burrknots on the tree trunk when grafted with the Galaxy and Fuji 
Suprema apple (Malus domestica) scion cultivars and cultivated on replanting soils.

\section{Acknowledgments}

To Fischer Fraiburgo Agrícola Ltda., for logistics support; and to Empresa de Pesquisa Agropecuária e Extensão Rural de Santa Catarina (Epagri), to Fundação de Amparo à Pesquisa e Inovação do Estado de Santa Catarina (Fapesc), to Financiadora de Estudos e Projetos (Finep), and to Associação Brasileira de Produtores de Maçã (ABPM), for incentive and financial support.

\section{References}

AUTIO, W.R.; ROBINSON, T.L.; BLACK, B.; BRADSHAW, T.; CLINE, J.A.; CRASSWELLER, R.M.; EMBREE, C.G.; HOOVER, E.E.; HOYING, S.A.; IUNGERMAN, K.A.; JOHNSON, R.S.; LANG, G.; PARKER, M.L.; PERRY, R.L.; REIGHARD, G.L.; SCHUPP, J.R.; STASIAK, M.; WARMUND, M.; WOLFE, D. Performance of 'Fuji' and 'McIntosh' apple trees after 10 years as affected by several dwarf rootstocks in the 1999 NC-140 apple rootstock trial. Journal of the American Pomological Society, v.65, p.2-20, 2011.

AUVIL, T.D.; SCHMIDT, T.R.; HANRAHAN, I.; CASTILLO, F.; MCFERSON, J.R.; FAZIO, G. Evaluation of dwarfing rootstocks in Washington apple replant sites. Acta Horticulturae, v.903, p.265-271, 2011. DOI: 10.17660/ActaHortic.2011.903.33.

CZYNCZYK, A.; BIELICKI, P. Eleven year evaluation of American $\left(\right.$ Geneva $\left.{ }^{\circledR}\right)$ and Polish rootstocks with 'Golden Delicious Reinders' apple in Poland. Journal of Fruit and Ornamental Plant Research, v.20, p.11-21, 2012. DOI: 10.2478/v10290-0120011-y.

DENARDI, F.; KVITSCHAL, M.V.; BASSO, C.; BONETI, J.I. da S.; KATSURAYAMA, Y. Performance of new apple rootstocks for Gala variety in Southern Brazil. Crop Breeding and Applied Biotechnology, v.16, p.147-152, 2016. DOI: 10.1590/1984-70332016v16n2n22.

DENARDI, F.; KVITSCHAL, M.V.; BASSO, C.; BONETI, J.I.S.; KATSURAYAMA, Y. Desempenho agronômico de porta-enxertos de macieira da série americana 'Geneva ${ }^{\circledR 1}$ no Sul do Brasil. Revista Brasileira de Fruticultura, v.37, p.104-111, 2015a. DOI: 10.1590/0100-2945-438/14.

DENARDI, F.; KVITSCHAL, M.V.; HAWERROTH, M.C. Portaenxertos de macieira: passado, presente e futuro. Agropecuária Catarinense, v.28, p.89-95, 2015b.

DENARDI, F.; KVITSCHAL, M.V.; SCHUH, F.S.; MANENTI, D.C. Efeito de porta-enxertos na indução da brotação da copa das macieiras 'Gala' e 'Fuji'. Agropecuária Catarinense, v.26, p.6163, 2013

EBERT, A.; PETRI, J.L.; BENDER, R.J.; BRAGA, H.J. First experiences with chill-unit models in Southern Brazil.
Acta Horticulturae, v.184, p.79-86, 1986. DOI: 10.17660/ ActaHortic.1986.184.8.

EPAGRI. A cultura da macieira. Florianópolis, 2006. 743p.

FAZIO, G.; ALDWINCKLE, H.; ROBINSON, T. Unique characteristics of Geneva ${ }^{\circledR}$ apple rootstocks. New York Fruit Quarterly, v.21, p.25-28, 2013.

FAZIO, G.; KVIKLYS, D.; GRUSAK, M.A.; ROBINSON, T. Soil $\mathrm{pH}$, soil type and replant disease affect growth and nutrient absorption in apple rootstocks. New York Fruit Quarterly, v.20, p.22-28, 2012.

FERREIRA, D.F. Sisvar: a computer statistical analysis system. Ciência e Agrotecnologia, v.35, n.6, p.1039-1042, 2011. DOI: 10.1590/S1413-70542011000600001.

FIORAVANÇO, J.C.; CZERMAINSKII, A.B.C; OLIVEIRA, P.R.D. de. Yield efficiency for nine apple cultivars grafted on two rootstocks. Ciência Rural, v.46, p.1701-1706, 2016. DOI: 10.1590/0103-8478cr20141754.

ISUTSA, D.K.; MERWIN, I.A. Malus germplasm varies in resistance or tolerance to apple replant disease in a mixture of New York orchard soils. HortScience, v.35, p.262-268, 2000.

JOHNSON, W.C. Methods and results of screening for disease and insect-resistant apple rootstocks. The Compact Fruit Tree, v.33, p.108-111, 2000.

KAIN, D.; ROBINSON, T.L. Planning bored. Scaffolds Fruit Journal, v.14, p.6-7, 2005.

KÜDELA, V.; KREJZAR, V.; KUNDU, J.K.; PÁNDOVÁ, I.; ACKERMANN, P. Apple burrknots involved in trunk canker initiation and dying of young trees. Plant Protection Science, v.45, p.1-11, 2009. DOI: 10.17221/38/2008-PPS.

KVITSCHAL, M.V.; DENARDI, F. Porta-enxertos de macieira - série JM: rebrotamento, incidência de 'burrknots' e eficiência produtiva no Meio-Oeste catarinense. In: ENCONTRO NACIONAL SOBRE FRUTICULTURA DE CLIMA TEMPERADO, 11., 2009, Fraiburgo. Anais. Caçador: Epagri, 2009. p.6.

LEINFELDER, M.M.; MERWIN, I.A. Management strategies for apple replant disease. New York Fruit Quarterly, v.14, p.39-42, 2006.

MARCON FILHO, J.L.; RUFATO, L.; RUFATO, A. de R.; KRETZSCHMAR, A.A.; ZANCAN, C. Aspectos produtivos e vegetativos de macieiras cv. Imperial Gala interenxertadas com EM-9. Revista Brasileira de Fruticultura, v.31, p.784-791, 2009. DOI: 10.1590/S0100-29452009000300023.

PASA, M. da S.; BONETI, J.I. da S.; BRIGHENTI, A.F.; SILVA, C.P. da. Desempenho produtivo de macieiras 'Fuji' em portaenxertos da série CG. Agropecuária Catarinense, v.30, p.61-65, 2017.

PASA, M. da S.; KATSURAYAMA, J.M.; BRIGHENTI, A.F.; ARAÚJO FILHO, J.V. de; BONETI, J.I. da S. Desempenho de macieiras 'Imperial Gala' e 'Mishima Fuji' em diferentes portaenxertos. Pesquisa Agropecuária Brasileira, v.51, p.17-26, 2016. DOI: 10.1590/S0100-204X2016000100003. 
PETRI, J.L.; LEITE, G.B.; COUTO, M.; FRANCESCATTO, P. Avanços na cultura da macieira no Brasil. Revista Brasileira de Fruticultura, v.33, p.48-56, 2011. Volume especial. DOI: 10.1590/ S0100-29452011000500007.

ROBINSON, T. Advances in apple culture worldwide. Revista Brasileira de Fruticultura, v.33, p.37-47, 2011. Volume especial. DOI: $10.1590 / \mathrm{S} 0100-29452011000500006$.

ROBINSON, T.L.; HOYING, S.A.; FAZIO, G. Performance of Geneva ${ }^{\circledR}$ rootstocks in on-farm trials in New York State. Acta Horticulturae, v.903, p.249-255, 2011. DOI: 10.17660/ ActaHortic.2011.903.31.

RUSSO, N.L.; ROBINSON, T.L.; FAZIO, G.; ALDWINCKLE, H.S. Field evaluation of 64 apple rootstocks for orchard performance and fire blight resistance. HortScience, v.42, p.15171525, 2007.
SOEJIMA, J.; BESSHO, H.; KOMORI, S.; TSUCHIYA, S. New apple rootstocks, ARM 1, ARM 7 and ARM 8. Acta Horticulturae, v.484, p.217-220, 1998. DOI: 10.17660/ActaHortic.1998.484.37.

WEBSTER, T. Dwarfing rootstocks: past, present and future. Compact Fruit Tree, v.35, p.67-72, 2002.

WHITE, M.; TUSTIN, S. New apple rootstocks alternative for the Southern Hemisphere. Compact Fruit Tree, v.33, p.112-115, 2000.

ZHU, Y.; FAZIO, G.; MAZZOLA, M. Elucidating the molecular responses of apple rootstock resistant to ARD pathogens: challenges and opportunities for development of genomicsassisted breeding tools. Horticulture Research, v.1, art.14043, 2014. DOI: $10.1038 /$ hortres.2014.43.

$\overline{\text { Received on June 24, } 2017 \text { and accepted on November 1, } 2017}$ 